\title{
Organizational and Economic Support of Educational Services Management in Ukraine
}

\author{
NATALIA O. KONDRATENKO ${ }^{1}$, OLEKSANDR M. NEPOMNYASHCHYY ${ }^{2}$, \\ OLEKSANDRA A. MARUSHEVA ${ }^{3}$, OKSANA V. MEDVEDCHUK ${ }^{4}$, IRYNA A. LAHUNOVA ${ }^{5}$ \\ ${ }^{1}$ Department of Management and Public Administration, O.M. BEKETOV NATIONAL UNIVERSITY OF URBAN \\ ECONOMY IN KHARKIV, Ukraine. E-mail: no.kondratenko6270-3@tanu.pro \\ 2,3,4,5 Department of Public Administration, INTERREGIONAL ACADEMY OF PERSONNEL MANAGEMENT, UKRAINE
}

\begin{abstract}
The article is focused on the development of the education system in the face of global challenges. Today, the education system is in the process of transformation, therefore, the question of finding ways to improve it is of real practical importance. The accessibility and quality of education is a global goal of sustainable development, identified as a priority for global human development by the United Nations. The latest trends in the development of the education system are defined in the article. Quarantine activities have identified problems of access to education for more than 7 million people in 190 countries. The absence of rational actions to increase the effectiveness of the educational process in the context of quarantine measures can lead to catastrophic consequences. The relevance and problems of the development of the education system in the context of social challenges are identified in the article. Education development issues are of important socio-economic importance, without the provision of effective institutional and economic mechanisms for the management of the educational process, it is impossible to ensure the sustainable development of mankind. There are considered certain aspects of the development of free and private education as forms of economic support in the article. Also, aspects of rationalization and increasing transparency of the financing of the education system are considered in the article. As a result of the analysis of the organizational and economic problems of increasing the efficiency of the educational process in the face of global challenges, the introduction of the concept of "technological educational process" is proposed, which will include processes of automation, digitalization and rationalization of the education system.
\end{abstract}

Keywords: private education, free education, quarantine, financing education system.

JEL Classification: 122, 125, 131 


\section{Introduction}

The development priority of any country is its education system, which forms the future potential for innovative development and socio-economic transformations in accordance with the requirements of modern society. States that have a high level of education and have a higher level of socio-economic development are dominated by innovative types of production, a high level of investment activity. So, education is an investment in the future of the country. In modern socio-economic conditions, the education system is at the stage of transformation, which is associated with the transition from a postindustrial to an information society for the introduction of digital technologies in all spheres of human activity, primarily in the educational sphere. And also, the challenges of the global coronavirus pandemic have identified new approaches and methods for providing knowledge and competencies in the context of a remote online training format. The problem of coronavirus also exposed the shortcomings of the education system, in particular those inherent in developing countries, and poor countries - this is the availability of education.

The United Nations is identifying the potential catastrophic consequences of the lack of access to even basic education, a problem that is scalable by the effects of quarantine activities and a practical lack of learning opportunities for children without access to the Internet. According to the UN Secretary General, who defined the position of the world community on problems in education in the note "Education in the pandemic era COVID-19 and subsequent years", which refers to the threat of loss of skills and competences (both basic, reading and writing, and professional) in several generations of students due to inaccessibility to the educational process (2). According to the world organization UNESCO, almost 1.6 billion learners worldwide have difficulty accessing the educational process due to the closure of schools for quarantine. This problem is global, as it has reached 190 countries and almost $95 \%$ of students (4). Thus, global challenges in the education system are a priority for the further sustainable development of society, and the lack of rational actions to improve the effectiveness of the educational process in the context of quarantine measures can lead to catastrophic consequences, which will set aside the world community for a number of years in its innovative development, will make it impossible to support this state of technological development, will contribute to the growth of ethical problems, the development of marginal manifestations and the general culture of mankind.

Taking into account the social significance and relevance of education development issues, it is useful to note the attention of domestic and foreign authors to the issue of organizational and economic support for the educational process. In particular, N.V. Mishchuk (2019) defined certain aspects of the formation of the foundations of organizational and economic support for the educational process at the national level. Yu.O. Romanenko and I.V. Chaplay (2016) highlighted the issue of education from the point of view of ensuring the development and security of individual territorial units and it is considered at the macro and mesoeconomic levels. M. Holovatyi (2014) defines the role of education in the formation of specific competencies, analyzed from the point of view of the role of vocational education in ensuring socio-economic processes. L.M. Hren (2019) proposed a new model of the education management system in the conditions of innovative challenges in the thesis research. Yu.O. Romanenko and I.V. Chaplay (2016) defines models of strategic development of higher education system in Ukraine, A.P. Lelechenko et al. (2020), O.A. Diegtiar, O.Y. Lebedinska, T.M. Derun, O.V. Berdanova, O.A Diegtiar (2020) Improving public water resources policy in Ukraine: Municipal and environmental issues. However, despite the attention of the authors to this issue, the problems of integrated organizational and economic support of the educational process in the context of new challenges and public priorities remain unresolved.

\section{Materials and Methods}

Having determined the relevance of the theme, the purpose of the research was formed, which is to find ways to increase the efficiency of organizational and economic support for the management of educational services in the face of new challenges and social transformations. A number of tasks have been identified according to the purpose: to determine the relevance and problems of the 
development of the education system in the context of social challenges; to review existing institutional arrangements and economic instruments for the development of the education system; to develop proposals to improve the efficiency of the system of organizational and economic support for educational process management.

The subject of the research is the global educational processes that are taking place in the world taking into account modern trends and tendencies, as well as the challenges of modern society. One of these global challenges was the coronavirus pandemic, which significantly limited the accessibility of education for many children and young people. The statistical data analyzed in the article is the result of an analysis of reports from international public organizations and government structures from different countries of the world, which determined the number of students who switched to distance learning. If we take into account the indicators of access of individual territories to the Internet, it is possible to determine the number of students who do not have the opportunity to acquire knowledge and the necessary skills to further compete in labor markets, both in their own country and in the world. This situation will also significantly affect the level of economic development of those countries that have the greatest problems in this situation with the availability of children to education. The main hypothesis of the article is the assertion that the results of coronavirus infection and the introduction of quarantine measures can be a loss of basic skills (reading, writing, counting) for a whole generation of children. The possibility of developing a delicate scenario of events, its prospects and possible ways out of this situation are considered in this article.

\section{Results and Discussion}

The education system is undergoing transformations caused by global challenges. Education is identified by the United Nations as one of the key goals for the further development of humankind in the list of 17 Sustainable Development Goals. However, the accessibility of the education system is a concern of the world community, which is associated with a number of global problems (2):

1) the problems of poverty and unemployment, as the level of commercialization of education increases in a number of regions, make education accessible only to a certain category of the population, leaving children from poor families without the possibility of education and further development;

2 ) the problem of non-education gives rise to growing problems of unemployment, low living standards, terrorism, drug addiction, world crime, military conflicts and other marginal manifestations, because an uneducated person who does not have basic skills and competencies for modern society cannot show his potential in socially important areas of activity;

3) low level of education causes problems of an economic nature, which is associated with the inability to provide workers with high-tech production, and outdated production methods lead not only to the creation of economic problems, but also have a negative environmental impact.

Thus, the development of the education system is of great socio-economic importance, without the provision of effective organizational and economic mechanisms for the management of the educational process, it is impossible to ensure the sustainable development of mankind. In the context of the global world pandemic of coronavirus, the level of access to education has decreased, which threatens to increase the level of global problems described above. Particularly significant are the problems of access to education due to the pandemic in South and West Asia (total number of pupils affected is 5.9 million), African countries, primarily south of the Sahara desert (5.3 million pupils). UNESCO predicts a reduction of 7.9 million students worldwide, with irreversible socio-economic consequences, especially in poor countries and developing countries (4). Thus, the description of the global challenges and transformations of education determines the need to establish new priorities and requirements for the sector's management.

Today, the education system can be divided into two areas: free education and commercial education. This classification not only determines the sources of funding for the educational process, but also affects the course of social processes in society significantly. UN determines the processes of 
education's commercialization as one of its problems. The commercialization of education involves the transition of educational institutions to a private form of ownership, the formation of private educational institutions, the main purpose of which, like any commercial enterprise or organization, is to profit (Mishchuk, 2019). Since the income of a commercial educational institution is formed only by paying the cost of training by the persons who are studying, the educational institution is therefore aimed at forming a revenue part to cover its own expenses and return on investment and ensure profitability for the owners of the institution (Hren, 2019). In this aspect, the social role of the educational institution is being relegated to the background. Of course, private educational institutions provide a service that is in demand on the market, in open competition.

However, the formation of demand for educational services is often dictated by the image component, concepts of prestige and uniqueness, the costs of advertising events that form interests in a particular educational product. The needs of the economic system are not always taken into account in formation of such demand. Thus, the commercialization of the education system has two main negative consequences: firstly, the restriction of access to education for children from poor families, secondly, the minimization of the social importance of educational services in the conditions of subordination of education to the interests of certain individuals, and not society as a whole. However, private education has its own advantages, in particular, they include a high level of teacher training, the development of effective teaching methods, a high level of technological support for the educational process (Romanenko et al., 2016). Such conditions dictate the requirements of high competitiveness in private education systems. Free education is the basis of access to education for all categories of people, regardless of their social level, income, standard of living or other factors.

In an environment where only/or predominantly public educational institutions operate at the state level, the issue of accessibility may arise in terms of access to transportation, Internet accessibility and inclusiveness of the educational space. Financing the education system is an important issue at the state level. However, since public education institutions are financed by the state budget in the context of the economic crisis and the decline in the economy due to quarantine activities, the question of finding sources of funding for education and rationalizing financial processes is of particular importance. According to statistics, the state spends UAH 21.000 per child who studies at a general education school in Ukraine every year. Total expenditure on school education amounts to UAH 83 million (Holovatyi, 2014; Nepomnyashchyy et al., 2019; latsyshyn et al., 2020). However, it should be noted, that the indicator of UAH 21 thousand is averaged and differs significantly in regions, territories, and even individual schools.

Moreover, an analysis of the school's performance by comparing the indicator of passing an external independent evaluation by pupils and the indicator of budget expenditures per pupil in an individual school showed that there is no direct relationship between these indicators. So, we can say that an increased level of budget funding does not provide a high result of the educational process. Direct dependence on the cost per pupil at school depends on the following factors: geographical remoteness of the school and the place of residence of pupils; population density of the territory and age structure of the population; creation of an inclusive educational space; increasing the autonomy of educational institutions; resolving the issue of education in the languages of national minorities; moral or physical deterioration of the fixed funds of educational institutions, low technology and equipment of educational institutions; an irrationally selected staff of teachers.

So, by analyzing the problems of financing educational institutions from the state budget, it can be determined that a number of problems are organizational in nature, and their solution lies in the plane of making rationalization management decisions. Therefore, in order to improve the cost-effectiveness of the training process, it is useful to consider rationalization of the following processes (Holovatyi, 2014; latsyshyn et al., 2020): formation of the staff of the educational institution and formation of the study load; ensuring rational logistics, if necessary, for the transportation of schoolchildren; technologization and ergonomics of the educational space. So, as a result of the analysis of organizational and economic problems of increasing the efficiency of the educational process in the face of global challenges, the introduction of the concept of "technological educational 
process" is proposed, which will include processes of automation, digitalization and rationalization of all educational processes. On the condition of the formation of a large number of educational institutions, the financing of their activities is essentially dispersed and does not give the desired effect (Ryzhkov, 2017). The processes of formation of supporting educational institutions provide a potential opportunity to increase the efficiency of the educational process and reduce the cost of operational activities of the educational institution. Such educational institutions should be constructed taking into account the following requirements (Al-Ababneh et al., 2020):

1) comprehensiveness of educational services, such as educational complexes, including preschool education, primary and secondary school education, profiled high school education and the formation of applicants who can consciously choose a higher education institution with the necessary professional knowledge, skills and competencies;

2) human resources capacity-building by maximizing the workload of each education worker. One of the problems of personnel policy in the education system is hidden unemployment. When teachers or professors work on part-time rates. This situation becomes the reasons for the decrease in the level of competence of the teacher, does not contribute to ensuring the improvement of his qualifications, does not provide financial motivation for the employee to work as efficiently as possible. The full workload of the employee, on the contrary, will increase the level of his involvement in the educational process;

3) technological re-equipment and modernization. The modern world requires from a person radically new skills, knowledge and skills as a full-fledged member of society. They are associated with digital transformation, the informatization of all operational processes, and the need to possess the so-called "soft skills", which require constant development and improvement. Obtaining such skills is possible only in the context of technological support for the educational process - computerization, providing access to high-speed Internet, access to additional educational information, knowledge of languages for access to global educational markets;

4) an important aspect of the rational expenditure of financial resources on technological development, rather than supporting operations, is to ensure the effectiveness of operational processes, which provides for energy efficiency, environmental compatibility, speed, automation of business processes, rationalization of logistics processes, ensuring transparency and ease of access to public information, in particular with regard to the assessment of learners' knowledge and skills, funding, expediture on the educational process and other key aspects of the educational process.

On the basis of the above, it can be concluded that the basis for the formation of an effective education system in the face of global challenges is the provision of rational organizational and economic management mechanisms. The basic element of this mechanism can be a public control system that ensures transparency and reliability of data for monitoring operational activities, attracting recognized experts in the education system and representatives of potential employers to form methodological support for the educational process, motivation (financial and non-financial) for employees of education for further training, retraining, obtaining new knowledge and skills for their introduction into the educational process in order to increase its effectiveness (Reikhanova , 2017; Putivzeva et al., 2019).

\section{Conclusion}

Thus, by analysing the challenges and prospects for the development of the educational system in the modern realities of the globalist world, it can be determined that education is a priority for the socio-economic development of the state. The development of education is the key to a successful future state. In the context of the information world, the development of technologies, and digitalization processes, only those countries that invest resources in the education of the younger generation can become successful. This will provide the country with the opportunity to introduce the latest technologies, which will ensure its competitiveness in various sectors of the economy. In turn, 
the development of business and the economy will contribute to the further development of the education system, which is the key to the development of the developed countries of the world. In turn, the low level of education does not allow the poorest countries to develop, leaving them with the problem of unskilled labor, the lack of technological production, and the development of an economy with minimal added value.

Today, one of the most pressing issues in the education system, taking into account the above in relation to poor countries, is the issue of the availability of education for all categories of the population. Accessibility is an urgent issue in the educational process. In the context of quarantine activities and the coronavirus pandemic, the problem of access to education has become global, which, according to world organizations, can negatively affect the skills and qualifications of several generations of learners. This problem will have both technological and social consequences. To reduce the impact of these processes on the socio-economic development of society, it is useful to develop effective organizational and economic mechanisms for managing the educational process in order to ensure the rationalization of operational processes, increase the effectiveness of teaching methods and ensure increased motivation of personnel, to build sustainable foundations for the development of education.

\section{References}

1. Al-Ababneh, H.A., \& Alrhaimi, S.A.S. (2020). Modern approaches to education management to ensure the quality of educational services. TEM Journal, 9(2), 770-8.

2. Critical situation in education: 24 million students are at risk of dropping out (2020). https://pon.org.ua/novyny/8114-kritichna-situacya-v-osvt-24-mlyoni-uchnv-rizikuyut-pokinutinavchannya.html [Accessed Jun 21, 2021].

3. Diegtiar, O.A. (2020). Improving public water resources policy in Ukraine: municipal and environmental issues. Journal of Advanced Research in Law and Economics, 3(43), 672-8.

4. Education transforms lives (2020). https://en.unesco.org/themes/education [Accessed Jun 21, 2021].

5. García-Zambrano, L., Rodríguez-Castellanos, A., \& García-Merino, J.D. (2020). Management of firms' intangibles and their impact on sustainable financial performance. Estudios De Economia Aplicada, 32(3), 1117-32.

6. Holovatyi, M. (2014). Multiculturalism as a means of nations and countries interethnic unity achieving. Economic Annals-XXI, 11-12, 15-8.

7. Hren, L.M. (2019). Functioning and filling of mechanisms of state administration. Public Administration and National Security, 2(21), 26-36.

8. latsyshyn, A.V., Kovach, V.O., Romanenko, Yu.O., Deinega, I.I., Popov, O.O., \& Lytvynova, S.H. (2020). Application of augmented reality technologies for preparation of specialists of new technological era. Augmented Reality in Education, 2547, 181-200.

9. Izquierdo, M.G.I.L., \& Carta, F. (2020). A progressive alternative to the linear structure of tuition fees in the Spanish higher education financing system. Estudios De Economia Aplicada, 32(3), 1097-116.

10. Lelechenko, A.P., Diegtiar O.A., Lebedinska, O.Y., Derun, T.M., \& Berdanova, O.V. (2020). Mechanisms of inter-state communications for solving sustainable development problems. Asia Life Sciences, 29(2), 1-9.

11. Mishchuk, N.V. (2019). Organizational and economic mechanism for regulating the development of education in Ukraine. Science Look: Economics and Management, 1(63), 42-7.

12. Nepomnyashchyy, O., Medvedchuk, O. \& Lahunova, I. (2019). Legal regulation of conformity assessment of personnel qualification in construction. Asia Life Sciences, 21(2), 405-14.

13. Putivzeva, N.P., Zaitseva, T.V., Udovenko, I.V., Pusnaya, O.P., Gakhova, N.N., \& Kaliuzhnaya, E.V. (2019). Development of the forecast model for management of the disbalance between the labor 
markets and educational services in the construction industry. Humanities and Social Sciences Reviews, 7(5), 951-9.

14. Reikhanova, I.V. (2017). Perspectives of use of competence-based approach to management in educational services market. Contributions to Economics, 9783319454610, 65-71.

15. Romanenko, Yu.O., \& Chaplay, I.V. (2016). Marketing communication system within public administration mechanisms. Actual Problems of Economics, 178(4), 69-78.

16. Romanenko, Yu.O. (2016). Place and role of communication in public policy. Actual Problems of Economics, 176(2), 25-6.

17. Ryzhkov, A.S. (2017). Development of project management methodology to provide educational services for global market. Proceedings of the 12th International Scientific and Technical Conference on Computer Sciences and Information Technologies, 1, article number 8098723.

18. Tomchuk, O., Tserklevych, V., Hurman, O., Petrenko, V., \& Chymosh, K. (2021). The efficiency of higher education institutions: evaluation and management of managers. Estudios De Economia Aplicada, 38(4), 4046. 